This is the author's final, peer-reviewed manuscript as accepted for publication. The publisher-formatted version may be available through the publisher's web site or your institution's library.

\title{
Canine insulinoma as a model for studying molecular genetics of tumorigenesis and metastasis
}

Thomas Schermerhorn

\section{How to cite this manuscript}

If you make reference to this version of the manuscript, use the following information:

Schermerhorn, T. (2013). Canine insulinoma as a model for studying molecular genetics of tumorigenesis and metastasis. Retrieved from http://krex.ksu.edu

\section{Published Version Information}

Citation: Schermerhorn, T. (2013). Canine insulinoma as a model for studying molecular genetics of tumorigenesis and metastasis. The Veterinary Journal, 197(2), 126-127.

Copyright: (c) 2013 Elsevier Ltd.

Digital Object Identifier (DOI): doi:10.1016/j.tvjl.2013.04.017

Publisher's Link: http://www.sciencedirect.com/science/article/pii/S1090023313001883

This item was retrieved from the K-State Research Exchange (K-REx), the institutional repository of Kansas State University. K-REx is available at http://krex.ksu.edu 
1 Guest Editorial

2

3 Canine insulinoma as a model for studying molecular genetics of tumorigenesis 4 and metastasis

5 Insulinoma is the most frequently diagnosed neuroendocrine pancreatic tumor of

7 dogs and humans. Most insulinomas of humans are treated effectively by surgical

8 excision. However, a subset of human insulinomas exhibits cellular characteristics and

9 clinical behavior consistent with malignancy and these are referred to as 'malignant

10 insulinoma'. Tumors of the latter type are therapeutically challenging and difficulties

11 are magnified because surgical excision of malignant insulinoma is rarely complete and

12 recurrence is likely, features which conspire to decrease survival times in affected

13 patients.

In the dog, the biologic course of insulinoma resembles that of malignant insulinoma in humans. Morbidity in dogs with insulinoma is usually due to the

17 functional capacity of the tumor rather than signs related to its physical presence. Until

18 hypoglycemia becomes apparent, the tumor with its high metastatic potential may elude

19 diagnosis. In the dog, as in humans, surgery along with post-operative chemotherapy is

20 still the recommended approach when possible. Despite the recent observation that

21 intensive management improves survival times (Polton et al., 2007), the high prevalence

22 of distant metastasis at diagnosis limits therapeutic options and translates to a poor long

23 term prognosis for affected dogs. Novel approaches are needed to improve diagnosis,

24 prognosis and therapy for canine and human insulinomas. 
26 Despite the clinical challenges associated with definitive treatment of canine 27 insulinoma, it is a well defined tumor syndrome that offers excellent opportunities for

28 molecular study of basic tumor biology. A series of recent papers by Dr Floryne

29 Buishand and colleagues of Utrecht and Maastricht Universities, including the study

30 that appears in this issue of Veterinary Journal (Buishand et al., 2013), both contribute

31 to our understanding of the molecular genetics of canine insulinoma and serve to

32 highlight the use of canine insulinoma as a valuable research model for the study of

33 tumorigenesis and metastasis.

Insulinomas in humans can occur as part of an inherited syndrome, designated multiple endocrine neoplasm type 1 (MEN1), but the majority of human insulinomas

37 arise sporadically and are due to an inherited genetic mutation (Jonkers et al., 2007).

38 Although there are reports of MEN-like syndromes in dogs, including one dog with an insulinoma (Kiupel et al., 2000), the role of MEN1, the gene responsible for the MEN syndrome, has not yet been investigated in canine insulinoma. However, no MEN1 coding mutations were found in a study of Keeshonds with familial

42 hyperparathyroidism (Skelly and Franklin, 2007). As in humans, the majority of

43 insulinomas occurring in dogs are considered to be 'sporadic'. The genetic alterations in

44 sporadic tumors are caused by somatic mutations, but the precise genes and the

45 molecular mechanisms involved that promote unrestrained cell growth and metastasis 46 remain poorly defined. 
Microarray studies of human insulinomas have revealed changes in expression

49 of genes involved in DNA repair, apoptosis and transcriptional regulation pathways

50 (Jonkers et al., 2007). In this issue, Buishand et al. (2013) used microarray analysis to

51 investigate the expression of a large number of genes $(>10,000)$ in primary canine

52 insulinomas and their metastases. Pathway analysis revealed down-regulation of

53 pathways involved in DNA damage repair, including breast cancer type 1 (BRCA1),

54 which is also abnormal in some human insulinomas, and pathways involved in cell

55 cycle regulation, including the ataxia telangiectasia mutated and Rad3-related

56 (ATM/ATR) pathway, which regulates entry into the cell cycle S phase. Substantial

57 differences in gene expression were also noted between primary insulinomas and their

58 corresponding metastases. Interestingly, a similar study of human insulinomas did not

59 find differences in gene expression profiles when primary insulinomas and their

60 metastasis were compared (Capurso et al., 2006).

Several other features of canine insulinomas identified by Buishand and colleagues, such as expression of growth hormone (Buishand et al., 2012) and, in the

64 current study, co-expression of genes typically expressed in the exocrine pancreas

65 (Buishand et al., 2013), are not frequently observed in human insulinomas or have not 66 yet been fully investigated (Wulbrand et al., 2000; Ordonez, 2001).

It is safe to assert that new targets for insulinoma therapy may be identified by

69 uncovering the pathways that permit unregulated growth and that facilitate distant

70 metastasis of tumor cells. While extrapolation of knowledge from human studies is

71 often the source of new approaches in veterinary medicine, the highlighted differences 
between canine and human insulinoma emphasize the need for focused studies of canine tumors. The work of Buishand and colleagues represents an important step forward in understanding the molecular genetics of canine insulinoma, particularly how these mechanisms dictate tumor growth and metastasis.

\author{
Thomas Schermerhorn \\ College of Veterinary Medicine \\ Kansas State University \\ Manhattan, Kansas, USA \\ E-mail address: tscherme@vet.k-state.edu
}

\title{
References
}

Buishand, F.O., Kirpensteijn, J., Jaarsma, A.A., Speel, E.J., Kik, M., Mol, J.A., 2013. Gene expression profiling of primary canine insulinomas and their metastases. The Veterinary Journal doi: 10.1016/j.tvjl.2013.01.021.

Buishand, F.O., van Erp MG, Groenveld HA, Mol JA, Kik M, Robben JH, Kooistra HS, Kirpensteijn J., 2012. Expression of insulin-like growth factor-1 by canine insulinomas and their metastases. The Veterinary Journal 191, 334-340.

Capurso, G., Lattimore, S., Crnogorac-Jurcevic, T., Panzuto, F., Milione, M., Bhakta, V., Campanini, N., Swift, S.M., Bordi, C., Delle Fave, G., Lemoine, N.R., 2006. Gene expression profiles of progressive pancreatic endocrine tumours and their liver metastases reveal potential novel markers and therapeutic targets. Endocrine Related Cancer 13, 541-558.

Jonkers, Y.M., Ramaekers, F.C., Speel, E.J., 2007. Molecular alterations during insulinoma tumorigenesis. Biochimica et Biophysica Acta 1775, 313-332.

Kiupel, M., Mueller, P.B., Ramos Vara, J., Irizarry, A., Lin, T.L., 2000. Multiple endocrine neoplasia in a dog. Journal of Comparative Pathology 123, 210-217.

Ordóñez, N.G., 2001. Insulinoma with fibrillar inclusions and acinar cell elements. Ultrastructural Pathology 25, 485-495.

Polton, G.A., White, R.N., Brearley, M.J., Eastwood, J.M., 2007. Improved survival in a retrospective cohort of 28 dogs with insulinoma. Journal of Small Animal Practice 48, 151-156. 
112

113

114

115

116

117

118

119
Skelly, B.J., Franklin, R.J., 2007. Mutations in genes causing human familial isolated hyperparathyroidism do not account for hyperparathyroidism in Keeshond dogs. The Veterinary Journal 174, 652-654.

Wulbrand, U., Remmert, G., Zöfel, P., Wied, M., Arnold, R., Fehmann, H.C., 2000. mRNA expression patterns of insulin-like growth factor system components in human neuroendocrine tumours. European Journal of Clinical Investigation 30, 729-739. 